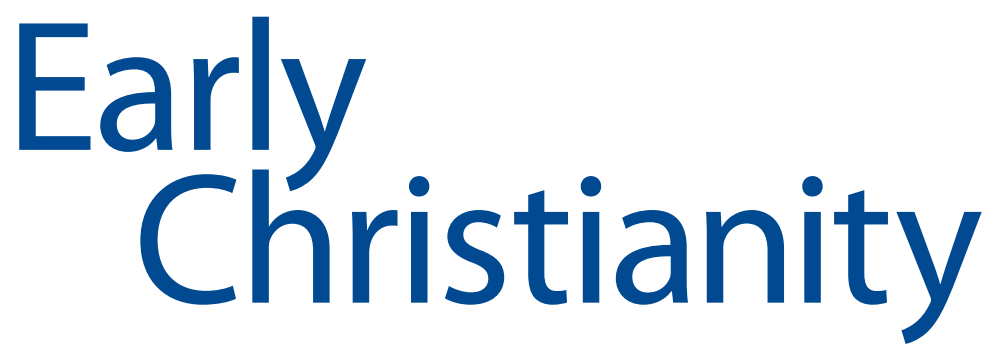

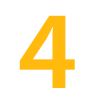

Volume 8 2017

Editorial

William Horbury

W.H.C. Frend on Martyrdom and Persecution: Links between Judaism and the Early Church 425-446

\title{
Dan Jaffé
}

Index Librorum Prohibitorum: The Tannaim and Jewish Christian Books; Philological and Historical Perspectives 447-457

\section{Tobias Nicklas}

Die Akten des Titus: Rezeption „apostolischer“ Schriften und Entwicklung antik-christlicher „Erinnerungslandschaften“"

458-480

\section{Torsten Jantsch}

"Sokratische“ Themen in der Areopagrede:

Apg 17,22-31 im Kontext der antiken Philosophiegeschichte 481-503

\section{New Projects}

Paola Buzi, Tracking Papyrus and Parchment Paths:

An Archaeological Atlas of Coptic Literature;

Literary Texts in Their Geographical Context;

Production, Copying, Usage, Dissemination and Storage (PAThs) 507-516

Christopher B. Zeichmann, Database of Military Inscriptions and Papyri of Early Roman Palestine (DMIPERP) 517-520

\section{New Books}

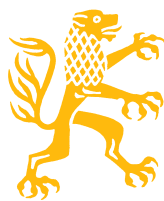

Bruce W. Longenecker, The Crosses of Pompeii: Jesus Devotion in a Vesuvian Town (Volker Michael Strocka) 523-528

John M.G. Barclay, Paul and the Gift (Francis Watson) 529-536

Mohr Siebeck

e-offprint of the author with publisher's permission 


\section{Early Christianity}

Herausgegeben von Jens Schröter (Geschäftsführender Herausgeber), Jörg Frey, Simon Gathercole und Clare K. Rothschild

Manuskripte und redaktionelle Anfragen werden an die Redaktion erbeten:

Prof. Dr. Jens Schröter

Redaktion Early Christianity

Humboldt-Universität zu Berlin

Theologische Fakultät

Unter den Linden 6

D-10099 Berlin

Germany

E-Mail: early-christianity@hu-berlin.de

Die Annahme zur Veröffentlichung erfolgt schriftlich und unter dem Vorbe-

halt, dass das Manuskript nicht anderweitig zur Veröffentlichung angeboten wurde. Mit der Annahme zur Veröffentlichung überträgt der Autor dem Verlag das ausschließliche Verlagsrecht. Das Verlagsrecht endet mit dem Ablauf der gesetzlichen Urheberschutzfrist. Der Autor behält das Recht, ein Jahr nach der Veröffentlichung einem anderen Verlag eine einfache Abdruckgenehmigung zu erteilen. Bestandteil des Verlagsrechts ist das Recht, den Beitrag fotomechanisch zu vervielfältigen und zu verbreiten, sowie das Recht, die Daten des Beitrags zu speichern und auf Datenträgern oder im Onlineverfahren zu verbreiten.

Für die Einreichung von Manuskripten sind die Richtlinien unter http://www.mohr.de/ec zu beachten. Die Herausgeber behalten sich vor, bei eingereichten Artikeln Änderungen zu verlangen.

\section{Online-Volltext}

Im Abonnement für Institutionen und Privatpersonen ist der freie Zugang zum Online-Volltext enthalten. Der Zugang gilt für einen Standort einer mittelgroßen Institution mit bis zu 40000 Nutzern (FTE). Als mehrere Standorte gelten Institutionen dann, wenn die Einrichtungen in unterschiedlichen Städten liegen. Multi-Sites und größere Institutionen bitten wir um Einholung eines Preisangebots direkt beim Verlag (Kontakt: elke.brixner@mohr.de). Um den Online-Zugang für Institutionen/Bibliotheken einzurichten, gehen Sie bitte zur Seite: www.ingentaconnect.com/register/institutional. Um den Online-Zugang für Privatpersonen einzurichten, gehen Sie bitte zur Seite: www.ingentaconnect.com/register/personal

Verlag: Mohr Siebeck GmbH \& Co. KG, Postfach 2040, 72010 Tübingen Vertrieb: erfolgt über den Buchhandel.

(C) 2017 Mohr Siebeck GmbH \& Co. KG, Tübingen

Die Zeitschrift und alle in ihr enthaltenen einzelnen Beiträge und Abbildungen sind urheberrechtlich geschützt. Jede Verwertung außerhalb der engen Grenzen des Urheberrechtsgesetzes ist ohne Zustimmung des Verlags unzulässig und strafbar. Das gilt insbesondere für Vervielfältigungen, Übersetzungen, Mikroverfilmungen und die Einspeicherung und Verarbeitung in elektronischen Systemen.

Printed in Germany.

Satz: Konrad Triltsch GmbH, Ochsenfurt.

Druck: Gulde-Druck, Tübingen.

ISSN 1868-7032 (Gedruckte Ausgabe)

ISSN 1868-8020 (Online-Ausgabe) 


\title{
Paola Buzi
}

\section{Tracking Papyrus and Parchment Paths: An Archaeological Atlas of Coptic Literature; Literary Texts in Their Geographical Context; Production, Copying, Usage, Dissemination and Storage (PAThs)}

\author{
A New Project on Coptic Literary Texts
}

Although the origins of Christianity in Egypt lie shrouded in uncertainty, the role of the former land of the pharaohs in the development of Christian thought in the early centuries of the Common Era should not be underestimated, especially given the strong and central role played in Christian theological speculations by the dynamic intellectual environment of Alexandria.

Because of its fortunate climatic conditions, Egypt has yielded an impressive amount of Coptic manuscript material, which constitutes a valuable source of primary data offering a rare opportunity to analyze the dynamics of the early stages of the spread of Christianity in Egypt, the making of its literature and writing practice, and, at the same time, its rooting in a specific territorial and environmental context: papyrus and parchment in situ finds have actually supplied the earliest surviving evidence of Coptic biblical texts, as well as of non-canonical or heterodox works, historiographic accounts, biographical reports, martyrdoms and sermons in a variety of dialects.

On the other hand, it is precisely this exceptional situation that attracted, especially from the end of the 19th century, systematic "excavations" whose goal was specifically to find and provide manuscripts, without any attention to their archaeological contexts, with imaginable consequences: several codices - and the texts they transmit - were acquired per se, in total disregard for the links to their original historical and geographical backgrounds. 
Despite these difficulties, Coptologists have tried to reconstruct a general development of Coptic literature, ${ }^{1}$ though the results of their efforts often appear artificial and desultory. A satisfactory "history of Coptic literature" remains a desideratum, ${ }^{2}$ in part because of a sometimes excessive scholarly specialization in single genres, with scholars dealing either exclusively with Nag Hammadi texts, or with Shenoutean production, etc.

Moreover, only very rarely have literary production and archaeological contexts been placed in relation to one another ${ }^{3}$ and studied as whole: as a rule, in Coptic studies - as in several other areas of research - art and archaeology on the one hand, and literature and history on the other, have always represented two, if not opposite, certainly almost independent fields of research. Although an understandable result of a traditional subdivision of competences, the result of such an approach has not facilitated dialogue among specialists. ${ }^{4}$ The new research project "PAThs" aims to solicit and encourage such a dialogue, as we will see.

\section{Coptic Literature: Its Evolution and Role in Early Christianity}

After three centuries of Ptolemaic rule, Roman Egypt appeared strongly marked by multiethnicity and multilingualism. If Egyptian (Demotic) continued to be used as the current language, Greek was the main linguistic tool for what concerned the literary production and all the bureaucratic aspects related to official affairs, while Latin had a marginal role, being the language of the cives romani (mainly soldiers) and law.

In such a complex cultural, religious and linguistic situation, despite the resistance of the traditional cults, Christianity slowly but progressively emerged. Although there are no concrete elements to confirm the tra-

1 One of the first scholars to have tried to sketch the history of Coptic literature was Tito Orlandi, who is also one of the strongest supporters of the necessity of a complete rethinking and more structured classification of Coptic literary production. Cf. T. Orlandi, Elementi di lingua e letteratura copta (Milan, 1970).

2 Such a situation has been recently stressed by A. Boud'hors, "The Coptic Tradition," in The Oxford Handbook of Late Antiquity (ed. S.F. Johnson; Oxford, 2012), 224-246.

3 Among the very few exceptions: E. Wipszycka, "La Vita Antonii confrontée avec la réalité géographique," in Aegyptus christiana: Mélanges d'hagiographie égyptienne et orientale (ed. U. Zanetti and E. Lucchesi; Geneva, 2004), 135-148.

4 Only recently have archeological expeditions started to work in teams which include from the first steps specialists of different disciplines, being the Institut français d'archéologie orientale in Cairo a forerunner in this respect. 
ditional attribution of the evangelization of Egypt to the apostle Mark, it is very likely that the new religion reached the Egyptian Mediterranean coast quite early and that it was perceived early on as a new and potentially strong cohesive factor. The role of Alexandria, the cultured city par excellence, with its renowned philosophical circles and institutions, was certainly determinative in this respect. ${ }^{5}$

From the end of the second century, the cultural richness of Christian Egypt was further increased by the emergence of a "new," partly artificial language that represents the last phase of the exceptionally long Egyptian linguistic tradition. ${ }^{6}$ This new phase of the Egyptian language, characterized by a variety of regional dialects, which was only later destined also to become a vernacular, was Coptic.

In the framework of a church in construction, it is not surprising that the first phase of the literary production in Coptic consisted of the systematic translation, from Greek, of biblical works (3rd-4th cent.). Egyptian Christianity, however, was not a homogeneous reality in the first centuries. Besides the translations of Old and New Testament works, therefore, we also find philosophical treatises that are to be referred to religious groups that, for doctrinal choices and exegetical practices, were rather different from those communities which represented the "orthodox" Christianity. This is the case, for instance, of the "Gnostic" texts found in Nag Hammadi and the Manichaean texts uncovered in Medinet Madi and Kellis. At the same time, however, other groups of people, belonging to a more traditional Christian milieu, were responsible for the translation of a large number of Greek homilies. This process, destined to last a long time, initially devoted its attention mainly to the production of the Cappadocian fathers and of John Chrysostom. Consequently, Coptic literature often preserves Greek works that have been lost in their original language.

Between the fourth and the fifth centuries Coptic Egypt was ready for a decisive step: the creation of an original literature, an enterprise for which the role of monasticism - one of the most significant cultural phenomena of Christian Egypt - was decisive. The celebration of a genuine, "national" religiosity embodied by figures of Egyptian anchorites, whose greatness lies in the choice of a modest life, became the fulcrum of several other texts produced at the same time or immediately after Pachomius's activity, who

5 S. Davis, The Early Coptic Papacy: The Egyptian Church and Its Leadership in Late Antiquity (Cairo, 2004).

6 J.P. Allen, The Ancient Egyptian Language: A Historical Study (Cambridge, 2013). 
founded the first coenobitic monastery whose life was regulated by a rule. The Apophthegmata patrum - that is, sentences attributed to the desert fathers - report several other figures of monks who are presented as models of genuine Egyptian Christianity.

With the figure of Shenoute, archimandrite of a confederation of monasteries coordinated by the so-called White Monastery, located not far from Panopolis, Coptic finally rose to the role of the literary language of Christian Egypt. ${ }^{7}$ To the deliberately "anti-literary" choice of Pachomius and his followers, which was expressed by the use of the genres of letters and rules, Shenoute opposed a complete adhesion to the genres of Greek and Alexandrian literature, becoming the author of homilies whose contents are extremely effective and engaging. In the Shenoutean production, besides the works realized for the monastic community, there was also space for texts inspired by the opposition to a plurality of heterodox currents, such as Origenism, Melitianism and Manichaeism. The vehemence expressed by Shenoute in his homilies reveals that Christian Egypt was experiencing one of its most critical moments as far as doctrinal disputes are concerned. ${ }^{8}$

The fifth century brings the most significant religious upheavals, culminating with the fracture of the Council of Chalcedon (451), which over time effected a separation, both dogmatic and hierarchical, from most of the other churches, with the slow but increasingly evident detachment of the Coptic literary tradition from the Greek "international" one. ${ }^{9}$ It is the real birth of the Coptic church: after the extremely confused hierarchical and religious phase that immediately followed the council, the separation of Egypt from the positions of the "Great Church" increased the Copts' pride in their identity, and literature was not long in supporting this orientation, above all by means of a historiographic production.

Between the fifth and sixth centuries both the original literary production and the translation work of homiletic texts went on. At the same time, in the Coptic literature, at its highest and fully-fledged linguistic potential, an interest for hagiographic texts, independent or more often collected in cycles, began to rise. These texts inherited the general characteristics of similar works previously translated from Greek, but had now mainly local martyrs as their main characters. The main result of such a

7 S. Emmel, Shenoute's Literary Corpus (2 vols.; CSCO 599-600; Leuven, 2004).

8 M. Simonetti, “Teologia e Cristologia nell'Egitto Cristiano," in L'Egitto cristiano: Aspettie problemi in età tardo-antica (ed. A. Camplani; Rome, 1997), 11-38.

9 T. Orlandi, "La letteratura copta e la storia dell'Egitto cristiano," in Le antiche Chiese orientali: Storia e letteratura (ed. P. Siniscalco; Rome, 2005), 85-117. 
literary process, which was to continue at least until the eighth century, are the so-called "epic martyrdoms," all characterized by some common elements: an evil emperor (usually Diocletian), an edict of persecution, a cruel judge, a long series of punishments imposed on the martyr and an equally long series of miracles made by him before and after his death. ${ }^{10}$

The sixth century, however, was also the era of the cultural circle gathered around the figure of patriarch Damian, who was responsible for the reorganization of the Egyptian church after the Chalcedonian schism. Beyond the individual personalities of the authors, the literary production of this period - destined to be used at the most important moments of aggregation (masses, festivals, celebrations of saints and martyrs) of the Egyptian $\dot{\varepsilon} \kappa \kappa \lambda \eta \sigma i a$ - had two main aims: firstly to preserve the Greek patristic texts which were compatible with the anti-Chalcedonian choice of Coptic Egypt, and secondly to produce new works that would serve the liturgical purposes of a church which was now completely independent.

The Arab conquest did not seem to affect Coptic literary production, which appeared to be, at least at an early stage, still quite lively. It was, however, inevitably a precarious balance. The last phase of Christian Egyptian literature written in Coptic was characterized by the selection and the rearrangement (sometimes by means of new titles) of those texts that appeared still useful for liturgical purposes and for the valorization of the local religious identity. An evident result of this work is the Alexandrian Synaxarium, consisting of a selection of hundreds of hagiographic texts arranged according to the liturgical calendar.

However, the Arabic language became increasingly intrusive, turning from a bureaucratic and legislative tool into the new exclusive language of all of Egypt. From the beginning of the eleventh century, a new phase began for Coptic literature, that is its translation into Arabic. ${ }^{11}$ It was the birth of Coptic-Arabic literature.

\section{Scope of the Project}

The purpose of "PAThs" is to offer an innovative approach to the study of the above-described evolution of Coptic literature and more specifically to the corpus of writings - almost exclusively of religious contents - pro-

10 H. Delehaye, "Les martyrs d'Égypte," AnBoll 40 (1922), 5-154, 299-364.

11 S. Rubenson, "Translating the Tradition: Some Remarks on the Arabization of the Patristic Heritage in Egypt," in Second Woodbrooke-Mingana Symposium on Arab Christianity and Islam (ed. D. Thomas; Leiden, 1996), 4-14. 
duced in Egypt between the third and the end of the eleventh centuries, and expressed in the different dialects of the Coptic language. Its aim is therefore to provide a new perspective on the cultural landscape of Christian Egypt, by interweaving literary, codicological and archaeological data, and producing a series of scholarly tools, till now unavailable, in a digital environment, among which an atlas of late antique and early medieval Egypt: this will be searchable at different chronological, regional and thematic levels, and is intended to illustrate the strong interconnection between the intellectual and the material production on the one hand, and the area of provenance on the other. In this respect, Christian Egypt represents a unique opportunity, since no other Mediterranean region has yielded such a rich archaeological and bibliological documentation.

It is not necessary to emphasize the fact that Egypt is to be considered an authentic laboratory for the progressive elaboration and perfection of what we define as "the book."12

"PAThs" will study Coptic books as material artifacts (showing how writing support [e.g., papyrus, parchment, paper], format and layout change according to contents and aims), as intellectual products (i.e., as a selection and combination of texts: particular attention will be devoted to multiple-text codices), but also - for the first time - as ritual objects (e. g., as part of a funerary kit), yet always strictly relating them to their archaeological settings.

In brief, by taking into account a large corpus of works, manuscripts and archaeological sites and interrelating them, the final purpose of "PAThs" is to produce a new state-of-the-art of Coptic studies, in which literature will no longer be considered a cultural phenomenon independent of its material context, and which will get beyond the traditionally narrow disciplinary subdivisions (especially in the fields of philology and archaeology) that have typified Coptic studies until now.

\section{Expected Results}

The ambitious purpose of the project is to trace a diachronic outline of the geography of Coptic literary production, which will be analyzed through

12 A. Petrucci, "Leggere nel Medioevo," in La lettura spirituale: Scrittori cristiani tra Medioevo ed età moderna (ed. L. Coco; Milan, 2005), 5-25; E. Crisci, "I più antichi codici miscellanei greci: Materiali per una riflessione," Segno e Testo 2 (2004), 109-144; R.S. Bagnall, Early Christian Books (Princeton, 2009). 
an innovative and pluridisciplinary approach, combining extensively philology, codicology, archaeology and digital humanities, in order to explore the entire process, from production to diffusion and storage, of Coptic works in relation to the geographical contexts of origin of both the texts themselves and their related writing supports.

By means of an analysis of philological aspects, dialects, style, content, scribal subscriptions, titles, and internal elements, the works will be related not only to the physical spaces where they were copied and disseminated but, what is more important, to those places where they were conceived, in order to reconstruct the identity of the cultural milieu (e.g., a monastic community or an episcopal see) responsible for the creation of literary genres and specific works. This approach is particularly congenial for hagiographic and monastic literary production (e.g., cycles of martyrdoms, which represent an important part of Coptic literature), where ideological and devotional motifs may be extremely telling.

The most obviously effective product of the project, as already said, will be an interactive, in-depth, and up-gradable atlas of late antique and early medieval Egypt, searchable at different chronological, regional and thematic levels and illustrating, among the other data, (1) the places where Coptic manuscripts have been found and/or produced, with a focus on monastic settlements, episcopal sees, tombs, and urban contexts (with a wealth of photos, plans, maps, etc.); (2) other works in combination with which a specific text was transmitted, in order to identify modes and ideologies in Coptic literary production, which were subject to change (e.g., the Vita Onuphrii was transmitted with different works in different periods), but also to the tastes of their particular patrons; (3) the plausible places where the works were conceived and created, with particular attention to monastic and hagiographic production, which provide more clues for such an investigation; (4) the codicological features of the manuscripts (book format, writing support, ${ }^{13}$ ruling system, presence of a binding, etc.) and their development in relation to a specific period and a specific region; (5) information related to the manuscript makers (places where they practiced their trade, places where they obtained their writing supports, etc.); and (6) information concerning the copyists (family relationships, normal professions, times of execution).

13 In Egypt the shift from papyrus to parchment writing support represents a technical innovation that has direct consequences on the number of works transmitted by a single manuscript and sometimes even on its contents. 
"PAThs" will integrate into its portal the aforementioned archaeological atlas of Coptic literature with several relational databases, all of them in keeping with the aim of creating a concrete link between literary production and related geographical and archaeological context:

(1) A complete classification of Coptic literature, by means of the attribution of a Clavis Coptica (CC) entry to each work and each title (this latter often being created later than the work to which it is attributed and therefore an independent literary product in itself), ${ }^{14}$ and a stable identifier to each colophon. Coptic colophons provide valuable information, such as names and professions of copyists - the latter often not working regularly as scribes -, places of copying, donors, etc., but they still have to be satisfactorily explored. As is well known, the CC classification has been initiated within the activities of the Corpus dei Manoscritti Copti Letterari (CMCL), ${ }^{15}$ but it needs to be expanded, refined and disseminated, in order to become a reliable tool for standard use among specialists of late antique Egypt.

(2) A complete classification of the Coptic manuscript tradition, by means of the attribution of stable identifiers to each manuscript, in order to have univocal coordinates of reference to the entire Coptic book production. Such a classification is progressively expandable as soon as new manuscripts are discovered. ${ }^{16}$

(3) A complete census of the relevant sites which are known as places where single manuscripts (e. g., codices buried with a body, as a funerary kit) or entire "collections" (e.g., a monastery library, such as the codices

14 P. Buzi, Titoli ed autori nella tradizione copta: Studio storico e tipologico (Pisa, 2005).

15 See http://www.cmcl.it/. The CMCL database, the core point of which is the (virtual) reconstruction of the codices from the White Monastery of Shenoute, the fragments of which are scattered in many collections worldwide, is an extremely important resource for "PAThs." The CMCL founder and director, Tito Orlandi, has guaranteed to "PAThs" the access to all the information collected in the CMCL database and archives, to be used as a solid basis for advancing in a territory that is so far unexplored.

16 This classification will take into consideration the results of previous and important projects, such as Trismegistos (http://www.trismegistos.org/), that, as is well known, is an interdisciplinary portal of papyrological and epigraphical resources which hosts a consortium of databases. One of the databases hosted by Trismegistos, the Leuven Database of Ancient Books, includes also a limited number of Coptic literary manuscripts, providing a search mask that makes it possible to search for a range of possibilities (per author, nomos/region, date, language, material, book format, etc.). Nonetheless, despite its undeniable merits, in regard to Coptic literature Trismegistos is not complete, since the majority of Coptic literary manuscripts fall outside of the chronological span taken into consideration by this portal. In the future, the results of "PAThs" will integrate the data provided by Trismegistos, without overlapping with its specific outcomes. 
found in the monastery of the Virgin Mary in Deir el-Hammām) have been found. Linking a specific room of a monastery or a private home (when possible) to a specific manuscript find helps in understanding the tastes, interests and cultural formation of the owner of that physical space and of the milieu to which (s)he belongs. For example, a copy of the Menandri sententiae was found in "cell A" of the Monastery of Epiphanius, at Thebes, together with school exercises in Greek and biblical extracts in Coptic, and so we have clues that the occupant was able to handle both languages, although at different levels, that his cultural formation also included gnomic literature, etc. A corpus of drawings, photos, maps (with particular attention to ancient documentation), and $3 \mathrm{D}$ reconstructions of the most relevant sites will be provided, to ensure the preservation of the memory of historical sites that in most cases have disappeared.

(4) A tentative identification of places and geographical areas where specific works and literary genres have been conceived. Such an attempt is particularly reasonable and sustainable for hagiographic and monastic literary production (e.g., cycles of martyrdoms, encomia of monastic characters, etc.), where ideological and devotional motifs may be extremely telling. By means of internal elements, style and titles the project will try to anchor a corpus of works to a specific place or to a limited geographical area.

(5) A complete archive of names of copyists, commissioners, donors, institutions and places involved in the production of manuscripts, which till now has been totally lacking. This will make it possible to reconstruct the cultural and economic relationships, which linked scribes and manuscripts makers to different monasteries, but also private citizens to patrons: a vivid portrait of the dynamics of book production as well as professional activities (leather production, "wastepaper" market, etc.) will thus emerge.

(6) A classification of the book formats, writing supports and other relevant codicological features of the manuscripts, in relation to the texts that they transmit.

All the databases just described - with their interrelated data - will constitute the invisible substructure of the atlas, making it not just an attractive website, but a freely accessible comprehensive and reliable tool, which will result in a rational classification and periodization of Coptic literature based on an accurate evaluation of the historical background (the passage from Roman - later Byzantine - Empire to the Islamic domination) and for the first time not devoid of a territorial dimension. 


\section{Further Information}

"PAThs - Tracking Papyrus and Parchment Paths: An Archaeological Atlas of Coptic Literature; Literary Texts in Their Geographical Context; Production, Copying, Usage, Dissemination and Storage" is an ERC Advanced project (2015). It is located in Sapienza University of Rome (Italy).

Its team is currently composed of Prof. Dr. Paola Buzi (Principal Investigator), Dr. Julian Bogdani (archaeologist and specialist of GIS and WebGIS and digital humanities applied to archaeology), Dr. Nathan Carlig (codicologist), Dr. Maria Chiara Giorda (historian), Dr. Agostino Soldati (philologist), Dr. Angela Bernardo (project coordinator with technical tasks). More members (codicologists, archaeologists and specialists of Coptic literature and early Christianity) are in the process of being recruited.

PAThs

Dipartimento di Storia Culture Religioni

Sapienza Università di Roma

Piazzale Aldo Moro 5

00185 Rome

Italy

http://paths.uniroma1.it 


\section{Early Christianity}

Edited by Jens Schröter (Managing Editor), Jörg Frey, Simon Gathercole and Clare K. Rothschild

Please send manuscripts and editorial inquiries to:

Prof. Dr. Jens Schröter

Redaktion Early Christianity

Humboldt-Universität zu Berlin

Theologische Fakultät

Unter den Linden 6

D-10099 Berlin

Germany

E-Mail: early-christianity@hu-berlin.de

Acceptance for publication will be given in writing, provided that the manuscript has not been offered for publication elsewhere. Upon acceptance, the author will transfer to the publisher the exclusive copyright for his/her work. This right to publish and sell the work expires with the termination of the duration of copyright stipulated by law. The author retains the right to grant another publishing company permission to reprint the work one year after the original publication. The right of publication comprises the right to reproduce the work photomechanically and the right to store the data in a retrieval system and to transmit it in online processing. Articles should conform to the stylistic guidelines, available at the publisher's website: http://www.mohr.de/ec. The editors reserve the right to specify revisions of submitted manuscripts.

\section{Full Text Online}

Free access to the full text online is included in a subscription. The subscription is valid for one location (single-site: one site $=$ one city) of a medium-sized institution (up to 40000 users). If your institution is larger than 40000 users (FTE), or has several locations, please contact the publisher to receive an offer.

Contact: elke.brixner@mohr.de. In order to set up online access for institutions/ libraries, please go to: http://www.ingentaconnect.com/register/institutional. In order to set up online access for private persons, please go to:

http://www.ingentaconnect.com/register/personal

Publisher: Mohr Siebeck GmbH \& Co. KG, Postfach 2040, 72010 Tübingen The journal may also be purchased at bookstores.

\section{(C) 2017 Mohr Siebeck GmbH \& Co. KG, Tübingen}

The journal and all the individual articles and illustrations contained in it are protected by copyright. Any utilization beyond the narrow confines of copyright law without the publisher's consent is punishable by law. This applies in particular to copying, translations, microfilming, and storage and processing in electronic systems.

Printed in Germany.

Typeset by Konrad Triltsch GmbH, Ochsenfurt.

Printed by Gulde-Druck, Tübingen.

ISSN 1868-7032 (Print Edition)

ISSN 1868-8020 (Online Edition) 


\section{Early \\ Christianity volume $8(2017)$, no.4}

“The journal is concerned with early Christianity as a historical phenomenon. Uncontroversial though that may sound, its editors share a quite specific understanding of this broad field of research. In seeking to further the study of early Christianity as a historical phenomenon, we aim to overcome certain limitations which - in our view - have hindered the development of the discipline. To identify a limitation is already to have seen the possibility of moving beyond it ...” From the Editorial Manifesto

Editors Jens Schröter, Berlin (Managing Editor) Jörg Frey, Zurich Simon Gathercole, Cambridge, UK Clare K. Rothschild, Chicago

Advisory Peter Arzt-Grabner, Salzburg Board Malcolm Choat, Sydney

(2017-2019) Klaus Hallof, Berlin Christos Karakolis, Athens John S. Kloppenborg, Toronto Annette Yoshiko Reed, Philadelphia Stephan G. Schmid, Berlin Daniel R. Schwartz, Jerusalem Janet Spittler, Charlottesville Jürgen K. Zangenberg, Leiden

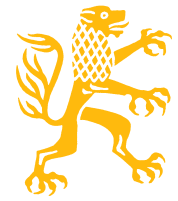

